\title{
lodide transport: implications for health and disease
}

\author{
Liuska Pesce $^{1 *}$ and Peter Kopp ${ }^{2}$
}

\begin{abstract}
Disorders of the thyroid gland are among the most common conditions diagnosed and managed by pediatric endocrinologists. Thyroid hormone synthesis depends on normal iodide transport and knowledge of its regulation is fundamental to understand the etiology and management of congenital and acquired thyroid conditions such as hypothyroidism and hyperthyroidism. The ability of the thyroid to concentrate iodine is also widely used as a tool for the diagnosis of thyroid diseases and in the management and follow up of the most common type of endocrine cancers: papillary and follicular thyroid cancer. More recently, the regulation of iodide transport has also been the center of attention to improve the management of poorly differentiated thyroid cancer. lodine deficiency disorders (goiter, impaired mental development) due to insufficient nutritional intake remain a universal public health problem. Thyroid function can also be influenced by medications that contain iodide or interfere with iodide metabolism such as iodinated contrast agents, povidone, lithium and amiodarone. In addition, some environmental pollutants such as perchlorate, thiocyanate and nitrates may affect iodide transport. Furthermore, nuclear accidents increase the risk of developing thyroid cancer and the therapy used to prevent exposure to these isotopes relies on the ability of the thyroid to concentrate iodine. The array of disorders involving iodide transport affect individuals during the whole life span and, if undiagnosed or improperly managed, they can have a profound impact on growth, metabolism, cognitive development and quality of life.
\end{abstract}

Keywords: lodide transport, lodine, Thyroid, Thyroid hormones, Hypothyroidism, Hyperthyroidism, Thyroid cancer, lodine deficiency, Radioactive iodine

\section{Introduction}

Iodine, as its water-soluble iodide ion $\left(\mathrm{I}^{-}\right)$, is the ratelimiting substrate for thyroid hormone synthesis. The availability of iodide depends on oral intake and the recommended daily allowances are summarized in Table 1 . Iodide is absorbed in the stomach and duodenum and cleared by the kidney and the thyroid. Seventy to eighty percent of the iodine body content is located in the thyroid gland and thyroid hormone synthesis requires a series of regulated steps. Altered regulation or defects in any of these steps can affect thyroid hormone synthesis and secretion. Furthermore, the understanding of iodide transport is used in the diagnosis, prevention and treatment of thyroid disorders and knowledge about the mechanisms underlying iodide transport is now applied to

\footnotetext{
* Correspondence: liuska-pesce@uiowa.edu

'Stead Family Department of Pediatrics, Division of Pediatric Endocrinology and Diabetes, University of lowa Carver School of Medicine, lowa City, lowa 52242, USA

Full list of author information is available at the end of the article
}

treat advanced forms of thyroid cancer and non-thyroidal malignancies.

\section{lodine intake and absorption}

Iodine, as iodide $\left(\mathrm{I}^{-}\right)$, is available but not equally distributed in the environment. Most iodide is found in the oceans (sea water has $50 \mu \mathrm{g} / \mathrm{L}$ ) and deficient soils are common in mountainous areas, regions that were glaciated and areas of frequent flooding; however, deficiency is also a problem in some coastal and island populations [2-5].

Plants grown in iodine deficient soils have as low as $10 \mu \mathrm{g} / \mathrm{kg}$ of dry weight, while plants grown in iodine rich soils have a concentration of $1 \mathrm{mg} / \mathrm{kg}$. Overall, the natural iodine content of many foods and beverages is low (3-80 $\mu \mathrm{g}$ per serving), while foods from marine origin have a higher content. However, sea salt has negligible amounts, as iodide in seawater is sublimated into the 
Table 1 Recommendations for iodine intake by age and population group from the World Health Organization (WHO), UNICEF and ICCIDD [1]

\begin{tabular}{lc}
\hline Age or population group & $\begin{array}{c}\text { Recommended daily } \\
\text { allowance }(\boldsymbol{\mu g})\end{array}$ \\
\hline Pre-school children (0-59 months) & 90 \\
\hline School children (6-12 years) & 120 \\
\hline Adolescents and adults (above 12 years) & 150 \\
\hline Pregnant and lactating women & 250 \\
\hline
\end{tabular}

atmosphere as volatile organic iodine [6]. The most important dietary sources of iodine in industrialized countries are breads containing iodized salt and milk [2]. Iodide absorption in the gastrointestinal tract is mediated by the sodium-iodide symporter (NIS), which also mediates the uptake of iodide into the thyroid follicular cell (see Figure 1) [7,8]. Iodide is rapidly cleared from the circulation by the thyroid gland and kidneys. Thyroid clearance varies depending on iodine intake, from $10 \%$ of absorbed iodide in healthy individuals to more than $80 \%$ in chronic iodine deficiency [2].

\section{lodide transport in thyroid cells}

As illustrated in Figure 1, the NIS (SLC5A5), a member of the solute carrier family 5 , located at the basolateral plasma membrane of the thyroid follicular cells actively transports iodide into the thyroid using the electrochemical gradient generated by the Na,K-ATPase [9-11]. This process also requires a constitutive active potassium channel consisting of the KCNQ1 and KCNE2 subunits promoting potassium efflux [12-14]. Iodide efflux into the follicular lumen is mediated in part by pendrin, in conjunction with an as of yet unidentified channel. Pendrin (SLC26A4), a member of the multianion transporter solute carrier 26 family, is a coupled electroneutral iodide/chloride, iodide/bicarbonate, and chloride/bicarbonate exchanger [15-17]. At the intraluminal side, iodide is oxidized, a reaction that requires hydrogen peroxide $\left(\mathrm{H}_{2} \mathrm{O}_{2}\right)$. The oxidation of iodide is mediated by thyroid peroxidase (TPO). TPO is also responsible for the iodination of selected tyrosil residues of thyroglobulin (organification), forming monoiodotyrosine (MIT) and diiodotyrosine (DIT) residues, and for the coupling of MIT and DIT resulting in the formation of $T_{3}$ and $T_{4}$

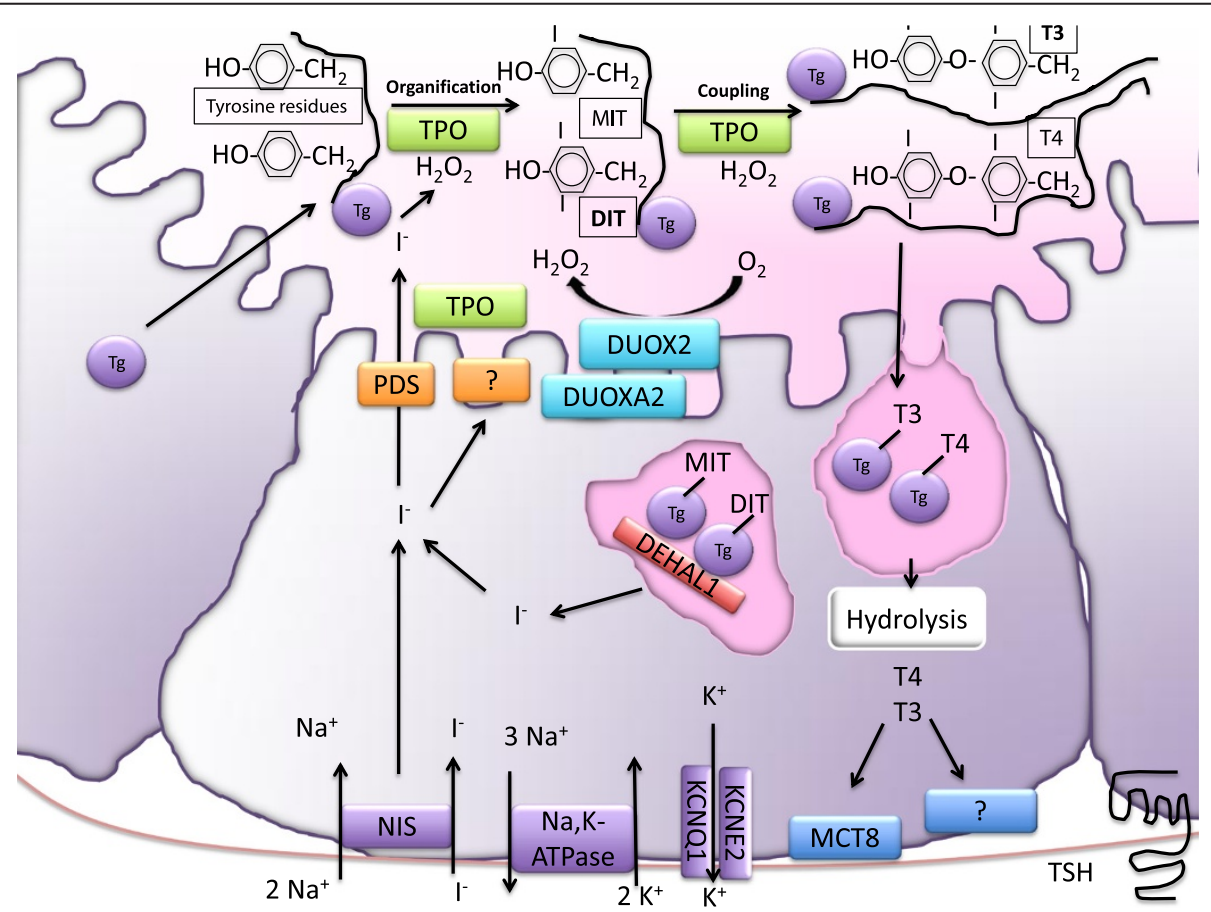

Figure 1 Mechanisms of lodide transport in thyroid follicular cells. The first step in iodide uptake is mediated by the sodium-iodide symporter NIS, using the sodium gradient generated by the Na, K-ATPase. Active transport of potassium by the KCNE2/KCNQ1 potassium channel is also important, likely for maintaining the membrane potential of thyroid cells. At the apical membrane, pendrin and another yet unidentified transporter mediate iodide efflux. TPO, using $\mathrm{H}_{2} \mathrm{O}_{2}$ generated by the DUOX2/DUOXA system mediates the oxidation, organification and coupling reaction that result in the synthesis of the iodothyronines T4 and T3. lodinated thyroglobulin is taken into the cell by micro- and macropinocytosis and digested in lysosomes. T4 and T3 are excreted via MCT8 and other transporters. The iodotyrosines MIT and DIT are dehalogenated by DEHAL1 and the released iodide is recycled. Purple boxes represent steps in basal iodide uptake. Orange boxes represent apical iodide uptake, oxidation, organification and coupling are mediated by TPO, represented in green boxes. The generation of $\mathrm{H}_{2} \mathrm{O}_{2}$ is represented in aqua. The recycling of iodide after digestion of iodinated thyroglobulin is represented in the red box. The secretion of thyroid hormones at the basolateral membrane is shown in the blue boxes. 
[18]. The matrix for the synthesis and storage of $\mathrm{T}_{4}$ and $\mathrm{T}_{3}$ is thyroglobulin ( $\mathrm{Tg}$ ), a large glycoprotein secreted by the thyroid follicular cells $[19,20] . \mathrm{H}_{2} \mathrm{O}_{2}$ is generated by the dual oxidase 2 (DUOX2), a calcium dependent flavoprotein NADPH oxidase, which requires a maturation factor known as DUOXA2 [21]. $\mathrm{T}_{3}$ and $\mathrm{T}_{4}$ are released into the bloodstream, following micro- or macropinocytosis and lysosomal digestion of thyroglobulin by endopeptidases and exopeptidases [22-24]. Animal and cellular models suggest that the monocarboxylate channel (MCT8/SLC16A2) is involved in the efflux of thyroid hormones at the basolateral membrane $[25,26]$. MIT and DIT are deiodinated by the iodotyrosine dehalogenase, DEHAL1. This allows the re-utilization of iodide within the thyroid cell [27]. The molar ratio of secreted T4 to T3 is 11 to 1 due to intrathyroidal deiodination of T4 to T3 by type 1 and 2 deiodinases (D1 and D2) [28]. However, most T3 production occurs in extrathyroidal tissues and both, T3 and T4 can be converted to inactive forms via deiodination of the inner ring, by either type 3 deiodinases (D3) or D1 [29,30].

\section{Regulation of iodide transport}

Iodide transport is dependent on the nutritional availability of iodide and on the stimulation of the thyroid stimulating hormone receptor (TSHR). Although the TSHR is constitutively active, it is susceptible to enhanced activation by TSH [31,32]. In addition, iodide uptake and organification are inhibited by high intracellular concentrations of iodide. Other factors have been shown to regulate iodide uptake, including thyroglobulin, cytokines, growth factors and estradiol.

\section{1) $\mathbf{T S H}$}

TSH stimulates thyroid hormone synthesis and secretion. TSH is a glycoprotein with two subunits. The $\alpha$ subunit is identical to the glycoprotein hormones LH, FSH and hCG, whereas the $\beta$ subunit is specific for the four hormones. TSH is synthesized and secreted in response to TSH releasing hormone (TRH) from the hypothalamus. Thyroid hormones negatively regulate the synthesis and secretion of both TRH and TSH. TSH stimulation of the G-protein coupled TSHR increases cAMP, which in turn, stimulates NIS transcription, half-life and subcellular distribution. TSH also upregulates the expression of TPO, Tg and the endocytosis of iodinated $\mathrm{Tg}$ [11] and increases the translocation of pendrin to the apical membrane of the thyroid follicular cell, thereby enhancing iodide efflux [33].

2) Iodide

Iodide is a major regulator of iodide accumulation and organification. Iodine intake has a negative effect on the expression of NIS and high doses of iodide block thyroid hormone synthesis via inhibition of organification (Wolff-Chaikoff effect) [34-37]. The adaptation to the initial inhibitory effect (the escape from the Wolff-Chaikoff effect) occurs as a result of decreased iodide transport. The escape is secondary to complex regulatory phenomena that involve, among others, decreased NIS gene transcription, increased NIS protein degradation and decreased NIS activity [38-40].

3) Thyroglobulin (Tg)

A role for $\mathrm{Tg}$ as an intrinsic regulator of iodide transport and thyroid hormone synthesis has been proposed to explain the heterogeneity of thyroid follicles and its differential expression of thyroid genes. Tg has been shown to decrease the gene expression of NIS, TPO, and DUOX [41-44].

\section{4) Cytokines and growth factors}

Cytokines such as TNF and interleukins inhibit iodide uptake and NIS expression. Insulin like growth factor 1 (IGF-1) affects thyroid hormone synthesis by downregulating the expression of NIS $[10,45-47]$. Transforming Growth Factor- $\beta$ (TGF- $\beta$ ) has been shown to downregulate iodide transport by several mechanisms in different species, including inhibition of mRNA expression of TSHR, TPO, NIS, the $\mathrm{Na}, \mathrm{K}-\mathrm{ATPase}$ and thyroglobulin [48].

\section{5) Estradiol}

Estradiol downregulates the expression of NIS and iodide uptake in thyroid cells, possibly explaining the higher incidence of goiter in women. Estradiol also upregulates thyroglobulin $[49,50]$.

\section{Thyroid conditions as they relate to iodide transport}

The different mechanisms and disorders associated with abnormal iodide transport are summarized in Table 2. For detailed explanation, please refer to the text.

\section{Disorders of iodine intake (DII)}

Iodine deficiency causes hypothyroidism and goiter. Moreover, it is associated with an increased risk for abortion and stillbirths, congenital malformations, increased perinatal mortality, impaired growth and developmental retardation, impaired mental potential and decreased productivity. Iodine deficiency in critical periods of brain development and growth causes severe and permanent growth and cognitive impairment (cretinism) as thyroid hormones are required for myelination, neuronal differentiation and formation of neural processes in the cerebral cortex, the basal ganglia and the inner ear during the first trimester of gestation, and subsequently for brain growth and differentiation [11,51-58]. Importantly, pregnant women need higher amounts of iodide (Table 1). Even mild iodine deficiency during pregnancy may affect outcomes [54,59-61]. However, despite the efforts from 
Table 2 Mechanisms and disorders associated with abnormal iodide transport

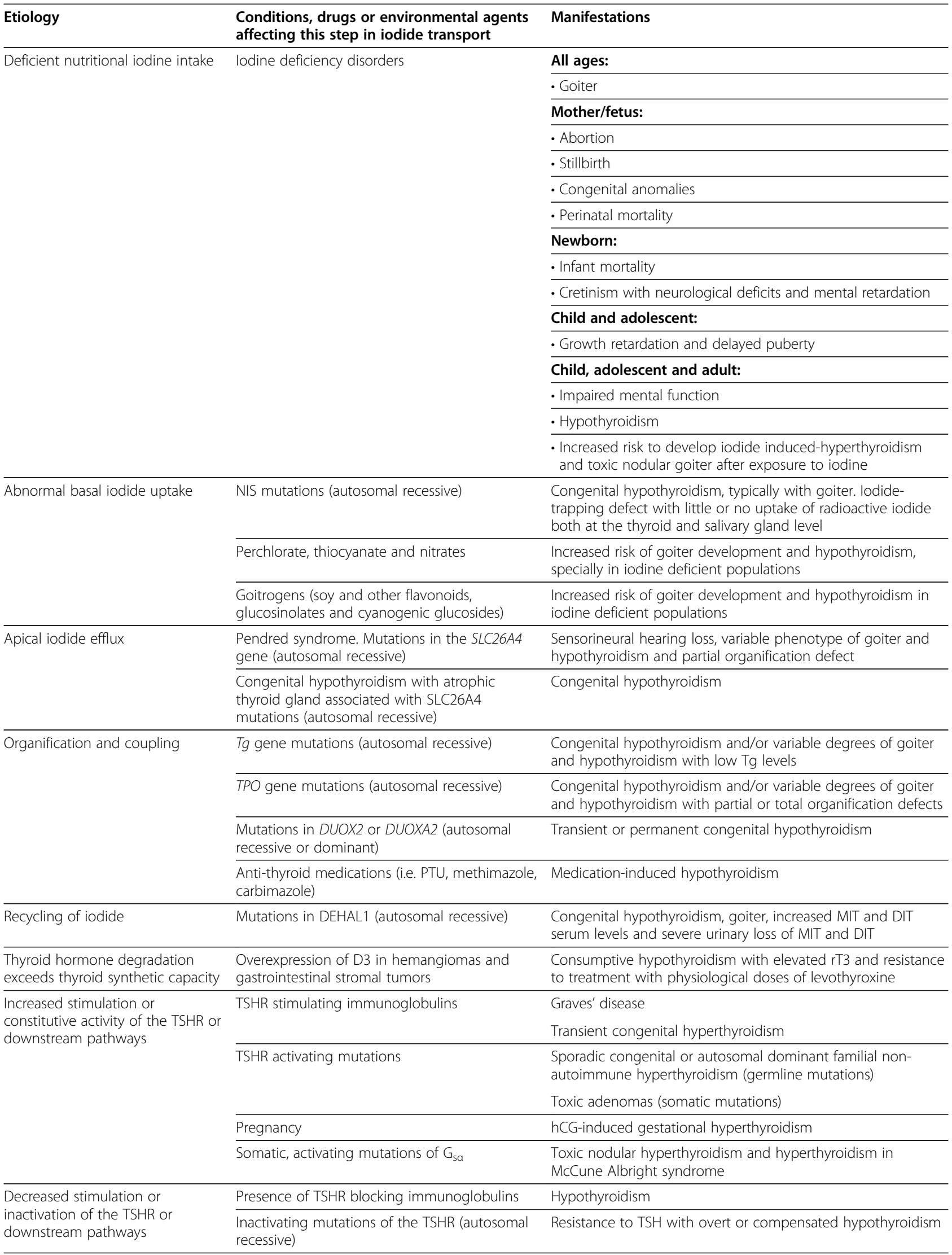


Table 2 Mechanisms and disorders associated with abnormal iodide transport (Continued)

\begin{tabular}{|c|c|c|}
\hline & Inactivating $\mathrm{G}_{\mathrm{sa}}$ mutations & $\begin{array}{l}\text { Hypothyroidism in the context of pseudohypoparathyroidism } \\
\text { type la }\end{array}$ \\
\hline \multirow{6}{*}{$\begin{array}{l}\text { lodide mediated alterations in } \\
\text { thyroid function }\end{array}$} & \multirow[t]{2}{*}{ lodine containing solutions } & Transient hypothyroidism (Wolff-Chaikoff effect) \\
\hline & & In iodine deficiency: Hyperthyroidism (Jod-Basedow) \\
\hline & \multirow{2}{*}{$\begin{array}{l}\text { lodine containing contrast agents (iodine } \\
\text { containing IV contrasts) }\end{array}$} & Transient hypothyroidism (Wolff-Chaikoff effect) \\
\hline & & In iodine deficiency: Hyperthyroidism (Jod-Basedow) \\
\hline & \multirow[t]{2}{*}{ Amiodarone } & $\begin{array}{l}\text { Amiodarone induced thyrotoxicosis (AIT): type 1: iodine } \\
\text { inducedthyrotoxicosis, Jod-Basedow type 2: thyroiditis }\end{array}$ \\
\hline & & $\begin{array}{l}\text { Amiodarone induced hypothyroidism (AMH); often associated } \\
\text { with underlying autoimmune thyroid disease }\end{array}$ \\
\hline $\begin{array}{l}\text { Other defects in thyroid hormone } \\
\text { release }\end{array}$ & Lithium & Hypothyroidism due to decrease release of T4 \\
\hline
\end{tabular}

the International Council for the Control of Iodine Deficiency Disorders (ICCIDD) to end a preventable form of hypothyroidism, goiter and mental retardation, thirty-two countries and about 246 million schoolchildren are estimated to have insufficient iodine intake $[4,5]$. In the US, the median urinary iodine concentration decreased by over $50 \%$ between the early 1970 s and the early 1990 s and even though most of the US population remains iodine sufficient, the aggregate data from NHANES 2007-2010 indicates that a subset of young women and pregnant women may have mild iodine deficiency [3]. Popular foods among young women, marketed for weight loss, are deficient in iodine [62]. Furthermore, prenatal vitamins have inconsistent amounts of iodide content [63,64]. Iodine supplementation is recommended not only for pregnancy, but also during lactation [65] as iodine supplementation given to a lactating mother provides adequate iodine to their infants [66]. Criteria for assessing iodine nutrition in populations based on school age children and in pregnant and lactating women are summarized in Table $3[2,4,58]$. Thyroglobulin is also a sensitive method to assess iodine intake $[67,68]$. Disorders of iodide transport (see below) are influenced by iodine intake. In addition, other questions remain, such as whether mild, transient congenital and/or subclinical hypothyroidism could be impacted by improving iodine intake.

\section{Disorders of iodide transport}

\section{1) Disorders associated with abnormal basolateral uptake}

Mutations in the NIS gene

Homozygous or compound heterozygous inactivating mutations of the NIS can cause congenital hypothyroidism. The thyroid may be normal at birth, but enlarges overtime due to TSH stimulation, unless thyroid hormone replacement is started. Affected individuals have an iodide-trapping defect with little or no uptake of radioactive iodide both in the thyroid and the salivary glands [69].

\section{2) Disorders associated with abnormal apical iodide efflux}

2.1) Pendred syndrome

Pendred syndrome is an autosomal recessive disorder caused by mutations in the PDS/ $S L C 26 A 4$ gene. It is characterized by sensorineural hearing loss associated with malformations of the inner ear (enlarged vestibular system), variable degrees of goiter and hypothyroidism and a partial iodine organification defect diagnosed by the perchlorate discharge test (see below) $[17,70,71]$.

2.2) Congenital hypothyroidism with hypoplastic thyroid gland due to PDS/SLC26A4 mutations

Table 3 Epidemiological criteria for assessing iodine nutrition based on median iodine urine concentration in school age children and median iodine concentration in pregnant women [1]

\begin{tabular}{lcc}
\hline Population & $\begin{array}{c}\text { Median urinary } \\
\text { iodine }(\boldsymbol{\mu g} / \mathbf{L})\end{array}$ & lodine intake \\
\hline $\begin{array}{l}\text { School age children } \\
\text { (older than 6 years old) }\end{array}$ & $<20$ & Insufficient (severe) \\
\cline { 2 - 3 } & $20-49$ & $\begin{array}{c}\text { Insufficient } \\
\text { (moderate) }\end{array}$ \\
\cline { 2 - 3 } & $50-99$ & Insufficient (mild) \\
\cline { 2 - 3 } & $100-199$ & Adequate \\
\cline { 2 - 3 } & $200-299$ & Above requirement \\
\hline Pregnant and lactating & $>300$ & Excessive \\
\cline { 2 - 3 } women & $150-249$ & Insufficient \\
\cline { 2 - 3 } & $250-499$ & Above requirements \\
\cline { 2 - 3 } & $>500$ & Excessive \\
\hline
\end{tabular}


Kühnen et al. [72] found biallelic mutations in the SLC26A4 gene in two individuals from two families with hypoplastic thyroid glands. They speculated that the hypoplasia may be caused by "secondary atrophy". However, the described mutations have also been reported in patients with Pendred syndrome, while the patients described in this study had thyroid hypoplasia. One case had apparently a normal hearing test. Nevertheless, imaging studies of the inner ear were not obtained. A second patient had deafness and mental retardation. The authors did not comment of the hearing function of the other four patients with hypoplastic thyroid glands harboring mutations on the SLAC26A4 gene. Moreover, the thyroid volumes of the index patients early in life are unknown [72]. Hence, it is not clear if patients presenting with hypoplastic thyroid glands may be within the spectrum of Pendred syndrome or not, and the mechanism causing thyroid atrophy needs to be further elucidated; it could, e.g., involve destruction of thyroid cells by the retained misfolded proteins [17].

\section{3) Disorders of organification and coupling}

\section{1) Thyroglobulin ( $\mathrm{Tg}$ )}

Biallelic mutations in the $\mathrm{Tg}$ gene can cause congenital hypothyroidism. The clinical spectrum ranges from normal thyroid function to overt hypothyroidism. The majority of patients have congenital goiter or develop goiter shortly after birth. The serum Tg concentrations are very low. Affected individuals are homozygous or compound heterozygous for inactivating mutations. Defective Tg molecules are typically retained in the ER and routed for degradation. However, some truncated proteins can be secreted and are sufficient for partial thyroid hormone synthesis $[19,73,74]$.

3.2) Thyroid peroxidase (TPO)

Recessive TPO defects are among the most common causes of congenital hypothyroidism secondary to dyshormonogenesis. Patients may have a partial or total organification defect. A recent study in the Netherlands found that TPO gene defects are the most common cause of a total organification defect, as diagnosed by a positive perchlorate test with a discharge of $>90 \%[75]$.

3.3) Dual oxidases and its chaperones (DUOX2/ DUOXA2)
DUOX1 and DUOX 2 are NADPH flavoproteins that share $83 \%$ sequence similarity. Both DUOX genes are expressed in the thyroid but their expression is not restricted to the thyroid. The DUOX2 and DUOXA2 genes are contiguous (together with their homologues $D U O X 1$ and DUOXA1) on the long arm of chromosome 15. Only mutations in DUOX2 and in DUOXA2 have been found to cause congenital hypothyroidism [21,76-78]. In some cases, transient hypothyroidism occurs. This was initially postulated to be secondary to heterozygous mutations, while biallelic DUOX2 mutations were thought to cause permanent hypothyroidism. However, transient hypothyroidism also occurs in individuals with biallelic mutations [77]. The role of DUOX1 in compensating for the loss of DUOX2 is unclear at this time and it is thought that iodide availability may also affect the phenotype.

\section{4) Disorder of intra-thyroidal iodide recycling}

4.1) Dehalogenase (DEHAL)

Mutations in the DEHAL1 gene (IYD) can cause congenital hypothyroidism, goiter, increased MIT and DIT serum levels and urinary loss of MIT and DIT $[27,79,80]$. Variable mental deficits can occur, depending on age of diagnosis and on whether hypothyroidism occurs during development $[11,79]$.

\section{Disorders of abnormal iodide transport regulation}

\section{1) Conditions affecting TSH signaling}

1.1) Hyperthyroidism

Conditions causing overstimulation of the TSHR increase iodide uptake and thyroid hormone synthesis. In Graves' disease, the production of TSHR-stimulating immunoglobulins causes increased thyroid cell proliferation, iodide uptake and thyroid hormone synthesis. These IgG antibodies can cross the placenta and are the most common cause of congenital hyperthyroidism [31,32,81]. Rarely, activating mutations of the TSHR are the cause of excessive iodide uptake and hyperthyroidism. They can present as somatic mutations in thyrotoxic adenomas, as autosomal dominant familial non-autoimmune hyperthyroidism, or as sporadic de novo germline mutations [31]. Activating mutations in the downstream $G$ protein $G_{s \alpha}$ can also cause non-autoimmune hyperthyroidism; this occurs through somatic mosaicism affecting thyroid cells in McCune 
Albright syndrome, or as isolated activating mutations in toxic adenomas [82,83]. During pregnancy, hCG stimulates iodide transport and thyroid hormone synthesis through stimulation of the TSHR. hCG has structural similarity to TSH and leads to a transient increase in thyroid hormone synthesis, resulting in lower TSH levels. In some women, the high hCG levels can cause overt hyperthyroidism and be associated with hyperemesis gravidarum. hCG-secreting trophoblastic tumors (hydatidiform mole, choriocarcinoma) are rare causes of hyperthyroidism [84].

1.2) Hypothyroidism Conditions causing a decreased or absent response of the TSHR to TSH cause inadequate iodide uptake and thyroid hormone synthesis. Autoimmune hypothyroidism can be caused by the presence of blocking thyrotropin binding inhibitor immunoglobulins (TBII). These antibodies cross the placenta and may cause transient congenital hypothyroidism $[85,86]$. Resistance to TSH can be caused by molecular defects affecting the transmission of the TSH stimulatory signal, most commonly due to biallelic loss of function mutations of the TSHR. The phenotypes vary from a hypoplastic thyroid gland with severe congenital hypothyroidism to mild hyperthyrotropinemia with an euthyroid state $[87,88]$. Inactivating mutations in the $G_{s \alpha}$ cause mild hypothyroidism, such as seen in pseudohypoparathyroidism [89-91].

\section{2) Iodine-induced conditions}

Medications or environmental agents can affect the concentration of intracellular iodide or its regulatory mechanisms. Amiodarone is an antiarrhytmic drug that contains two atoms of iodine in an inner benzene ring, similar to thyroid hormones. Each $200 \mathrm{mg}$ tablet of amiodarone contains 75,000 $\mu$ g of iodine [92]. It can cause amiodarone-induced thyrotoxicosis (AIT) via two different mechanisms. AIT type 1 , which occurs more frequently in iodine deficient areas, is caused by excessive thyroid hormone synthesis by nodular thyroid tissue that has lost its autoregulatory capacity (Jod-Basedow phenomenon; Jod = iodine in German; Karl von Basedow $=$ German physician who described thyrotoxicosis associated with exophthalmos and goiter) [93-97]. The Jod-Basedow effect can be caused by any form of iodine excess such as contrast agents or iodine-containing solutions [98-101]. Currently used, water soluble iodinated contrast agents provide exposure to about $13,500 \mu \mathrm{g}$ of free iodine per computerized tomography (CT) imaging study [92]. AIT type 2 occurs secondary to amiodarone-induced thyroiditis. Amiodarone can also cause hypothyroidism $(\mathrm{AIH})$, particularly in patients with underlying autoimmune thyroid disease. Lithium is another widely used drug known to affect thyroid function. Among other effects, it appears to promote iodide retention in the thyroid and it decreases the release of thyroid hormone from the gland [102-104]. Other effects of amiodarone and lithium are reviewed elsewhere [93-96,102-105].

\section{Consumptive hypothyroidism}

Hemangiomas and gastrointestinal stromal tumors may express high levels of D3. This enzyme catalyzes the conversion of $\mathrm{T} 4$ to $\mathrm{rT} 3$ and of $\mathrm{T} 3$ to $\mathrm{T} 2$, i.e. inactive forms of thyroid hormone. This causes a unique form of hypothyroidism due to increased degradation of thyroid hormones at a rate that exceeds the synthetic capacity of the stimulated thyroid gland [106-108]. These patients have significantly elevated rT3 levels and require unusually large doses of levothyroxine in order to compensate for the increased degradation of $\mathrm{T} 4$ and $\mathrm{T} 3$.

\section{Drugs, diet and environmental agents affecting iodide transport and metabolism}

\section{1) Perchlorate, thiocyanate and other environmental agents}

In addition to its iodide transport activity, NIS also transports other anions [11,109], including selenocyanate $\left(\mathrm{SeCN}^{-}\right)$, thiocyanate $\left(\mathrm{SCN}^{-}\right)$, chlorate $\left(\mathrm{ClO}^{-}\right)$, and nitrate $\left(\mathrm{NO}_{3}{ }^{-}\right)$. Pertechnetate $\left(\mathrm{TcO}_{4}\right)$, perrhenate $\left(\mathrm{ReO}_{4}{ }^{-}\right)$and perchlorate $\left(\mathrm{ClO}_{4}{ }^{-}\right)$are also NIS substrates [11]. Perchlorate is a competitive NIS inhibitor. Perchlorate salts are used as oxidizers in solid propellants for a wide range of uses; perchlorate is not biodegradable and it is found in drinking water, food and multivitamins $[110,111]$. The Environmental Protection Agency (EPA) established a minimum reporting level (MRL) of $4 \mu \mathrm{g} / \mathrm{L}$ [112]. Perchlorate can be transported by NIS into the thyroid and the mammary gland, which would potentially decrease iodide supply in the breast milk and affect the newborn's iodide uptake by the thyroid gland [113]. Kirk et al. found an inverse correlation between breast milk iodine and perchlorate concentration [114]. However, other studies do not show a similar correlation $[115,116]$. 
In healthy adults, exposure to perchlorate for 6 months with doses as high as $3 \mathrm{mg} /$ day did not affect thyroid function [117] and thus, the consequences of environmental perchlorate exposure still remain controversial [111]. Thiocyanate is a less potent inhibitor of NIS-mediated iodide transport than perchlorate. Exposure to thiocyanate comes mainly from cigarette smoke (containing cyanide, which is metabolized to thiocyanate) and from the diet (see below). Smoking seems to affect iodide secretion into the breast milk [118]. The available studies trying to address the effect of smoking on thyroid function are not conclusive. It appears that smoking is associated with goiter and hypothyroidism in iodine deficient regions, whereas smokers have lower TSH levels in iodine sufficient areas $[119,120]$. Although the risks of perchlorate and thiocyanate exposure in healthy adults remain unresolved, a recent study indicates that a combination of perchlorate and thiocyanate exposure with low iodine intake lowers free thyroxine concentration by about $12 \%$ [121]. Nitrates are widely present in soils and water and come from natural decomposition of organic materials. Sodium nitrite is also used as a preservative. The average intake of nitrates in adults is $75-100 \mathrm{mg} /$ day and $80 \%$ comes from vegetables. Vegetarians may ingest 2.5 times the average intake. High ingestion of nitrates usually comes from contaminated water. The EPA defined the maximum contaminant level at $10 \mathrm{mg} / \mathrm{L}$ or $10 \mathrm{ppm}$ [112]. Exposure to high levels of nitrates due to polluted water has been shown to cause thyroid dysfunction and goiter $[122,123]$.

2) Medications used to treat hyperthyroidism The anti-thyroid drugs used in the US include propyl-thiouracil (6-propyl-2-thiouracil) and methimazole (1-methyl-2-mercaptoimidazole). Carbimazole, which is metabolized to methimazole, is widely used in other parts of the world. These thionamide drugs are actively concentrated in the thyroid and their primary effect consists in inhibiting the TPO-mediated organification [124].

\section{3) Diet}

Cruciferous vegetables like cabbage, kale, broccoli, turnips and cauliflower contain glucosinolates. Cassava (linamarin), lima beans, sweet potatoes, sorghum and flaxseed contain cyanogenic glucosides. Both, glucosinolates and cyanogenic glucosides are metabolized to thiocyanate that competes for thyroid iodide uptake. These substances can aggravate iodine deficiency and contribute to goiter development. Hence, they are called goitrogens. Soy and millet contains flavonoids that may inhibit TPO activity. Use of soy-based formula without added iodide can produce hypothyroidism and goiter in healthy infants [125-128].

\section{lodine as a tool for diagnosis and treatment of thyroid disorders}

The ability of the thyroid to concentrate iodide is widely used in the diagnosis and treatment of thyroid disorders. Commonly used diagnostic tests such as the radioactive iodine uptake and (whole body) scan rely on the ability of thyroid tissue to concentrate radioactive labeled iodine. $\mathrm{I}^{-131}, \mathrm{I}^{-123}$ and $\mathrm{I}^{-124}$ (a positron emission tomography (PET) tracer) are the major radionuclide agents used for the diagnosis of thyroid diseases (Table 4). These tests can be used to differentiate a hyperactive thyroid, with increased uptake (e.g. Graves' disease, toxic nodules), from an underactive thyroid with decreased iodine uptake, secondary to either thyroid damage or inactivation (e.g. thyroiditis, factitious thyrotoxicosis) or a blockade in thyroid uptake (e.g. mutation in NIS). Whole body scans with radioactive iodine are useful for the staging and planning of therapy of well-differentiated thyroid cancer [129]. Because of the ability of NIS to transport pertechnetate $\left(\mathrm{TcO}_{4}{ }^{-}\right),{ }^{99} \mathrm{TcO}_{4}{ }^{-}$, an isotope with no $\beta$ emission and a short half-life, can be used to image thyroid tissue (see Table 3) [130-132]. The perchlorate $\left(\mathrm{ClO}_{4}{ }^{-}\right)$discharge test is a functional test that uses $\mathrm{ClO}_{4}{ }^{-}$to inhibit NIS and radioactive iodine to diagnose partial or total organification defects. This test relies on the fact that iodide transported into the thyroid is covalently bound to $\mathrm{Tg}$ (organification). Radioactive iodide is administered,

Table 4 Radionuclides used for evaluation and management of thyroid disorders [132]

\begin{tabular}{|c|c|c|c|}
\hline Radionuclide & Radioactive emissions ( $\mathrm{keV}^{*}$ ) & Half-life & Clinical use \\
\hline $123 \mathrm{I}$ & Y $159 \mathrm{keV}$ & 13.2 hours & Thyroid and whole body scanning \\
\hline \multirow[t]{2}{*}{${ }^{131} \mathrm{I}$} & Y $364 \mathrm{keV}$ & 8.09 days & Thyroid and whole body scanning \\
\hline & $\beta 637 \mathrm{keV}$ & & Treatment of Graves' disease, toxic adenomas, thyroid cancer \\
\hline $124 I$ & $\beta^{+}$(positron emitter) y $603 \mathrm{keV}$ & 4.2 days & Whole body scanning Dosimetry \\
\hline${ }^{99} \mathrm{~m}_{\mathrm{c}} \mathrm{O}_{4}$ & Y $140 \mathrm{keV}$ & 6 hours & Thyroid scanning \\
\hline
\end{tabular}


followed by radioactive uptake measurement in the neck using a gamma camera. Two hours later, uptake is blocked using the competitive NIS inhibitor $\mathrm{ClO}_{4}{ }^{-}$ and the radioisotope counts are measured again over the next hour. Organified iodine is retained, while free, unbound iodide is washed out. A test is considered positive if $>10 \%$ of activity is discharged after $\mathrm{ClO}_{4}{ }^{-}$ administration. Partial organification defects show a $10-90 \%$ discharge, while discharge $>90 \%$ is consistent with total organification defect [19,21,133-135].

\section{lodine in the prevention of thyroid disorders and public health}

Potassium iodide and potassium perchlorate can be used to protect the thyroid from exposure to I-131 after accidental release from nuclear plant reactors to prevent hypothyroidism and thyroid cancer [136].

\section{New developments in iodide transport in the diagnosis and management of thyroid cancer}

Poorly differentiated thyroid cancer cells show decreased or absent iodide uptake. This is associated with decreased expression or membrane insertion of NIS at the plasma membrane. For this, reason, there is a great interest in re-differentiating agents that increase NIS expression and membrane insertion [11]. For example, selumetinib, a MAPK (MEK1/MEK2) inhibitor can result in improved radioactive iodine uptake and retention in some patients with radioiodide resistant thyroid cancer [137].

\section{Applications of iodide transport outside the thyroid}

Outside the thyroid, non-regulated iodide accumulation, without organification, is known to occur in the lactating mammary gland, salivary and parotid glands, gastric mucosa, small intestine, choroid plexus and the ciliary body of the eye $[11,46]$. In addition, NIS is expressed in other tissues [138], however, the physiological relevance of NIS in these tissues in unclear, except in the lung, where oxidation of iodide improves anti-viral defenses [11,139]. Endogenous NIS expression occurs in breast cancer and cholangiocarcinoma. Currently, ongoing research is exploring the use of ${ }^{131} \mathrm{I}^{-}$to treat these types of cancers. The fact that NIS transports perrhenate defines ${ }^{188} \mathrm{ReO}_{4}{ }^{-}$as a candidate to increase radiation dose delivery to these tumors [11]. Transduction of viral vectors containing the cDNA of NIS under the control of heterologous promoters (e.g. the PSA promoter) are used experimentally in order to treat other malignancies (such as prostate cancer) [140].

\section{Conclusions}

In conclusion, iodide transport is of essential physiological importance for thyroid hormone synthesis. The understanding of iodide transport and its regulation has been fundamental in characterizing the spectrum of thyroid disorders. The ability of thyroid follicular cells to concentrate iodide can be used for diagnostic and therapeutic purposes and the elucidation of the molecular events governing iodide uptake also has important implications because it allows to target NIS for redifferentiation therapies and to use it in non-thyroidal tissues.

\section{Abbreviations \\ D1: Type 1 deiodinase; D2: Type 2 deiodinase; D3: Type 3 deiodinase; DIT: Diiodotyrosine; DUOX: Dual oxidase; DEHAL1: Dehalogenase; $\mathrm{H}_{2} \mathrm{O}_{2}$ : Hydrogen peroxide; ICCIDD: International Council for the Control of Iodine Deficiency Disorders; MIT: Monoiodotyrosine; PDS: Pendrin NIS: Sodium iodide symporter; Tg: Thyroglobulin; T3: Triiodothyronine; T4: Thyroxine; TPO: Thyroid peroxidase; TRH: TSH releasing hormone; TSH: Thyroid Stimulating Hormone; TSHR: TSH-receptor; WHO: World Health Organization; US: United States.}

\section{Competing interests}

The authors declare that they have no competing interests.

\section{Authors' contributions}

LP made significant contributions to the conception, planning, review of literature, writing, reviewing and editing the manuscript. PK made significant contributions to reviewing content, editing and approving the final version of the manuscript. Both authors read and approved the final manuscript.

\section{Author's information}

LP is a Clinical Assistant Professor of Pediatric Endocrinology with interest in pediatric thyroid disorders and thyroid physiology. PK is an Associate Professor of Endocrinology and he is the director ad interim of the Center of Genetic Medicine at Northwestern University. His clinical focus is directed towards thyroid dysfunction and thyroid cancer. His research interests include genetic endocrine disorders, in particular of the thyroid and the pituitary gland.

\section{Acknowledgements}

LP is grateful to Alejandro Comellas for his critical appraisal, which contributed to the final version.

\section{Author details}

${ }^{1}$ Stead Family Department of Pediatrics, Division of Pediatric Endocrinology and Diabetes, University of lowa Carver School of Medicine, lowa City, lowa 52242, USA. ${ }^{2}$ Department of Internal Medicine, Division of Endocrinology, Metabolism and Molecular Medicine, Feinberg School of Medicine,

Northwestern University, Chicago, Illinois 60611, USA

Received: 18 February 2014 Accepted: 22 May 2014

Published: 30 May 2014

\section{References}

1. Asessment of iodine deficiency disorders and monitoring their elimination A guide for programme managers. [http://www.who.int/nutrition/ publications/micronutrients/iodine deficiency/9789241595827/en/index.html]

2. Zimmermann MB: lodine deficiency. Endocr Rev 2009, 30(4):376-408.

3. Pearce EN, Andersson M, Zimmermann MB: Global iodine nutrition: Where do we stand in 2013? Thyroid 2013, 23(5):523-528.

4. Zimmermann MB, Andersson M: Update on iodine status worldwide. Curr Opin Endocrinol Diabetes Obes 2012, 19(5):382-387.

5. International Council for the Control of lodine Deficiency Disorders [http://www.iccidd.org]

6. Victor R, Preedy GNBaRW: Comprehensive Handbook of iodine. Oxford: Academic Press; 2009.

7. Nicola JP, Reyna-Neyra A, Carrasco N, Masini-Repiso AM: Dietary iodide controls its own absorption through post-transcriptional regulation of the intestinal Na+/l- symporter. J Physiol 2012, 590(Pt 23):6013-6026. 
8. Nicola JP, Basquin C, Portulano C, Reyna-Neyra A, Paroder M, Carrasco N: The $\mathrm{Na}+/ \mathrm{l}$ - symporter mediates active iodide uptake in the intestine. Am J Physiol Cell Physiol 2009, 296(4):C654-C662.

9. Carrasco N: lodide transport in the thyroid gland. Biochim Biophys Acta 1993, 1154(1):65-82.

10. Dohan O, De la Vieja A, Paroder V, Riedel C, Artani M, Reed M, Ginter CS, Carrasco N: The sodium/iodide Symporter (NIS): characterization, regulation, and medical significance. Endocr Rev 2003, 24(1):48-77.

11. Portulano C, Paroder-Belenitsky M, Carrasco N: The Na+/l- Symporter (NIS): Mechanism and Medical Impact. Endocr Rev 2014, 35(1):106-149.

12. Roepke TK, King EC, Reyna-Neyra A, Paroder M, Purtell K, Koba W, Fine E, Lerner DJ, Carrasco N, Abbott GW: Kcne2 deletion uncovers its crucial role in thyroid hormone biosynthesis. Nat Med 2009, 15(10):1186-1194.

13. Frohlich H, Boini KM, Seebohm G, Strutz-Seebohm N, Ureche ON, Foller M, Eichenmuller M, Shumilina E, Pathare G, Singh AK, Seidler U, Pfeifer KE, Lang F: Hypothyroidism of gene-targeted mice lacking Kcnq1. Pflugers Arch 2011, 461(1):45-52.

14. Purtell K, Paroder-Belenitsky M, Reyna-Neyra A, Nicola JP, Koba W, Fine E, Carrasco N, Abbott GW: The KCNQ1-KCNE2 K(+) channel is required for adequate thyroid I(-) uptake. FASEB J 2012, 26(8):3252-3259.

15. Bizhanova A, Kopp P: Controversies concerning the role of pendrin as an apical iodide transporter in thyroid follicular cells. Cell Physiol Biochem 2011, 28(3):485-490.

16. Wolff J: What is the role of pendrin? Thyroid 2005, 15(4):346-348

17. Kopp P: Mutations in the Pendred Syndrome (PDS/SLC26A) Gene: An Increasingly Complex Phenotypic Spectrum From Goiter to Thyroid Hypoplasia. J Clin Endocrinol Metab 2014, 99(1):67-69.

18. Ruf J, Carayon P: Structural and functional aspects of thyroid peroxidase. Arch Biochem Biophys 2006, 445(2):269-277.

19. Targovnik HM, Esperante SA, Rivolta CM: Genetics and phenomics of hypothyroidism and goiter due to thyroglobulin mutations. $\mathrm{Mol}$ Cell Endocrinol 2010, 322(1-2):44-55.

20. Citterio CE, Machiavelli GA, Miras MB, Gruneiro-Papendieck L, Lachlan K, Sobrero G, Chiesa A, Walker J, Munoz L, Testa G, Belforte FS, GonzálezSarmiento R, Rivolta CM, Targovnik HM: New insights into thyroglobulin gene: molecular analysis of seven novel mutations associated with goiter and hypothyroidism. Mol Cell Endocrinol 2013, 365(2):277-291.

21. Grasberger $\mathrm{H}$ : Defects of thyroidal hydrogen peroxide generation in congenital hypothyroidism. Mol Cell Endocrinol 2010, 322(1-2):99-106.

22. Dunn AD, Myers HE, Dunn JT: The combined action of two thyroidal proteases releases $\mathrm{T} 4$ from the dominant hormone-forming site of thyroglobulin. Endocrinol 1996, 137(8):3279-3285.

23. Dunn AD, Crutchfield HE, Dunn JT: Proteolytic processing of thyroglobulin by extracts of thyroid lysosomes. Endocrinol 1991, 128(6):3073-3080.

24. Dunn AD, Crutchfield HE, Dunn JT: Thyroglobulin processing by thyroidal proteases. Major sites of cleavage by cathepsins B, D, and L. J Biol Chem 1991, 266(30):20198-20204.

25. Friesema EC, Jansen J, Jachtenberg JW, Visser WE, Kester MH, Visser TJ: Effective cellular uptake and efflux of thyroid hormone by human monocarboxylate transporter 10. J Mol Endocrinol 2008, 22(6):1357-1369.

26. Di Cosmo C, Liao XH, Dumitrescu AM, Philp NJ, Weiss RE, Refetoff S: Mice deficient in MCT8 reveal a mechanism regulating thyroid hormone secretion. J Clin Invest 2010, 120(9):3377-3388.

27. Kopp PA: Reduce, recycle, reuse-iodotyrosine deiodinase in thyroid iodide metabolism. N Engl J Med 2008, 358(17):1856-1859.

28. Laurberg P: Mechanisms governing the relative proportions of thyroxine and 3,5,3'-triiodothyronine in thyroid secretion. Metabolism 1984, 33(4):379-392.

29. Gereben B, Zeold A, Dentice M, Salvatore D, Bianco AC: Activation and inactivation of thyroid hormone by deiodinases: local action with general consequences. Cell Mol Life Sci 2008, 65(4):570-590.

30. Bianco AC, Salvatore D, Gereben B, Berry MJ, Larsen PR: Biochemistry, cellular and molecular biology, and physiological roles of the iodothyronine selenodeiodinases. Endocr Rev 2002, 23(1):38-89.

31. Davies TF, Ando T, Lin RY, Tomer Y, Latif R: Thyrotropin receptor-associated diseases: from adenomata to Graves disease. J Clin Invest 2005, 115(8):1972-1983.

32. Michalek K, Morshed SA, Latif R, Davies TF: TSH receptor autoantibodies. Autoimmun Rev 2009, 9(2):113-116.

33. Pesce L, Bizhanova A, Caraballo JC, Westphal W, Butti ML, Comellas A, Kopp $\mathrm{P}$ : TSH regulates pendrin membrane abundance and enhances iodide efflux in thyroid cells. Endocrinol 2012, 153(1):512-521.
34. Wolff J, Chaikoff IL: The inhibitory action of excessive iodide upon the synthesis of diiodotyrosine and of thyroxine in the thyroid gland of the normal rat. Endocrinol 1948, 43(3):174-179.

35. Wolff J, Chaikoff IL: Plasma inorganic iodide as a homeostatic regulator of thyroid function. J Biol Chem 1948, 174(2):555-564.

36. Wolff J, Chaikoff IL, Goldberg RC, Meier JR: The temporary nature of the inhibitory action of excess iodine on organic iodine synthesis in the normal thyroid. Endocrinol 1949, 45(5):504-513. illust.

37. Uyttersprot N, Pelgrims N, Carrasco N, Gervy C, Maenhaut C, Dumont JE, Miot F: Moderate doses of iodide in vivo inhibit cell proliferation and the expression of thyroperoxidase and $\mathrm{Na}+/ \mathrm{l}-$ symporter mRNAs in dog thyroid. Mol Cell Endocrinol 1997, 131(2):195-203.

38. Eng PH, Cardona GR, Fang SL, Previti M, Alex S, Carrasco N, Chin WW, Braverman LE: Escape from the acute Wolff-Chaikoff effect is associated with a decrease in thyroid sodium/iodide symporter messenger ribonucleic acid and protein. Endocrinol 1999, 140(8):3404-3410.

39. Braverman LE, Ingbar SH: Changes in Thyroidal Function during Adaptation to Large Doses of lodide. J Clin Invest 1963, 42:1216-1231.

40. Eng PH, Cardona GR, Previti MC, Chin WW, Braverman LE: Regulation of the sodium iodide symporter by iodide in FRTL-5 cells. Eur J Endocrinol 2001 144(2):139-144.

41. Sellitti DF, Suzuki K: Intrinsic Regulation of Thyroid Function by Thyroglobulin. Thyroid 2014, 24(4):625-638.

42. Yoshihara A, Hara T, Kawashima A, Akama T, Tanigawa K, Wu H, Sue M, Ishido Y, Hiroi N, Ishii N, Yoshino G, Suzuki K: Regulation of dual oxidase (DUOX) expression and H2O2 production by thyroglobulin. Thyroid 2012, 22(10):1054-1062.

43. Suzuki K, Kawashima A, Yoshihara A, Akama T, Sue M, Yoshida A, Kimura HJ: Role of thyroglobulin on negative feedback autoregulation of thyroid follicular function and growth. J Endocrinol 2011, 209(2):169-174.

44. Ishido Y, Yamazaki K, Kammori M, Sugishita Y, Luo Y, Yamada E, Yamada T, Sellitti DF, Suzuki K: Thyroglobulin suppresses thyroid-specific gene expression in cultures of normal, but not neoplastic human thyroid follicular cells. J Clin Endocrinol Metab 2014, 99(4):E694-E702.

45. Dohan $\mathrm{O}$, Carrasco $\mathrm{N}$ : Advances in $\mathrm{Na}(+) /(-)$ symporter (NIS) research in the thyroid and beyond. Mol Cell Endocrinol 2003, 213(1):59-70.

46. Riesco-Eizaguirre G, Santisteban P: A perspective view of sodium iodide symporter research and its clinical implications. Eur J Endocrinol 2006, 155(4):495-512.

47. Garcia B, Santisteban P: PI3K is involved in the IGF-I inhibition of TSHinduced sodium/iodide symporter gene expression. Mol Endocrinol 2002, 16(2):342-352

48. Pisarev MA, Thomasz $L$, Juvenal GJ: Role of transforming growth factor beta in the regulation of thyroid function and growth. Thyroid 2009, 19(8):881-892.

49. Furlanetto TW, Nunes RB Jr, Sopelsa AM, Maciel RM: Estradiol decreases iodide uptake by rat thyroid follicular FRTL-5 cells. Braz J Med Biol Res 2001, 34(2):259-263.

50. Santin AP, Furlanetto TW: Role of estrogen in thyroid function and growth regulation. J Thyroid Res 2011, 2011:875125.

51. Delange F: The role of iodine in brain development. Proc Nutr Soc 2000 59(1):75-79.

52. de Escobar GM, Obregon MJ, del Rey FE: lodine deficiency and brain development in the first half of pregnancy. Public Health Nutr 2007, 10(12A):1554-1570.

53. de Escobar GM, Ares S, Berbel P, Obregon MJ, del Rey FE: The changing role of maternal thyroid hormone in fetal brain development. Semin Perinatol 2008, 32(6):380-386.

54. Zimmermann MB: The adverse effects of mild-to-moderate iodine deficiency during pregnancy and childhood: a review. Thyroid 2007, 17(9):829-835.

55. Melse-Boonstra A, Jaiswal N: lodine deficiency in pregnancy, infancy and childhood and its consequences for brain development. Best Pract Res Clin Endocrinol Metab 2010, 24(1):29-38.

56. Horn $\mathrm{S}$, Heuer $\mathrm{H}$ : Thyroid hormone action during brain development: more questions than answers. Mol Cell Endocrinol 2010, 315(1-2):19-26.

57. Zimmermann MB: The effects of iodine deficiency in pregnancy and infancy. Paediatr Perinat Epidemiol 2012, 26(Suppl 1):108-117.

58. Zimmermann MB: The role of iodine in human growth and development. Semin Cell Dev Biol 2011, 22(6):645-652.

59. Bath SC, Rayman MP: lodine deficiency in the U.K.: an overlooked cause of impaired neurodevelopment? Proc Nutr Soc 2013, 72(2):226-235. 
60. Hynes KL, Otahal P, Hay I, Burgess JR: Mild iodine deficiency during pregnancy is associated with reduced educational outcomes in the offspring: 9-year follow-up of the gestational iodine cohort. J Clin Endocrinol Metab 2013, 98(5):1954-1962.

61. Bath SC, Steer CD, Golding J, Emmett P, Rayman MP: Effect of inadequate iodine status in UK pregnant women on cognitive outcomes in their children: results from the Avon Longitudinal Study of Parents and Children (ALSPAC). Lancet 2013, 382(9889):331-337.

62. Kuriti M, Pearce EN, Braverman LE, He X, Leung AM: lodine content of U.S. weight-loss food. Endocr Pract 2014, 20(3):232-235.

63. Zimmermann M, Delange F: lodine supplementation of pregnant women in Europe: a review and recommendations. Eur J Clin Nutr 2004, 58(7):979-984

64. Leung AM, Pearce EN, Braverman LE: lodine content of prenatal multivitamins in the United States. N Engl J Med 2009, 360(9):939-940.

65. Public Health Committee of the American Thyroid A, Becker DV, Braverman LE, Delange F, Dunn JT, Franklyn JA, Hollowell JG, Lamm SH, Mitchell ML, Pearce E, Robbins J, Rovet JF: lodine supplementation for pregnancy and lactation-United States and Canada: recommendations of the American Thyroid Association. Thyroid 2006, 16(10):949-951.

66. Bouhouch RR, Bouhouch S, Cherkaoui M, Aboussad A, Stinca S, Haldimann M, Andersson M, Zimmermann MB: Direct iodine supplementation of infants versus supplementation of their breastfeeding mothers: a double-blind, randomised, placebo-controlled trial. Lancet Diabetes Endocrinol 2014, 2(3):197-209.

67. Zimmermann MB, Andersson M: Assessment of iodine nutrition in populations: past, present, and future. Nutr Rev 2012, 70(10):553-570.

68. Zimmermann MB, Aeberli I, Andersson M, Assey V, Yorg JA, Jooste P, Jukic T, Kartono D, Kusic Z, Pretell E, San Luis TO Jr, Untoro J, Timmer A: Thyroglobulin is a sensitive measure of both deficient and excess iodine intakes in children and indicates no adverse effects on thyroid function in the UIC range of 100-299 mug/L: a UNICEF/ICCIDD study group report. J Clin Endocrinol Metab 2013, 98(3):1271-1280.

69. Spitzweg C, Morris JC: Genetics and phenomics of hypothyroidism and goiter due to NIS mutations. Mol Cell Endocrinol 2010, 322(1-2):56-63.

70. Kopp P, Bizhanova A: Clinical and molecular characteristics of Pendred syndrome. Ann Endocrinol 2011, 72(2):88-94.

71. Bizhanova A, Kopp P: Genetics and phenomics of Pendred syndrome. Mol Cell Endocrinol 2010, 322(1-2):83-90.

72. Kuhnen P, Turan S, Frohler S, Guran T, Abali S, Biebermann H, Bereket A, Gruters A, Chen W, Krude H: Identification of PENDRIN (SLC26A4) Mutations in Patients With Congenital Hypothyroidism and "Apparent" Thyroid Dysgenesis. J Clin Endocrinol Metab 2014, 99(1):E169-E176.

73. Medeiros-Neto G, Kim PS, Yoo SE, Vono J, Targovnik HM, Camargo R, Hossain SA, Arvan P: Congenital hypothyroid goiter with deficient thyroglobulin. Identification of an endoplasmic reticulum storage disease with induction of molecular chaperones. J Clin Invest 1996, 98(12):2838-2844.

74. Medeiros-Neto G, Targovnik HM, Vassart G: Defective thyroglobulin synthesis and secretion causing goiter and hypothyroidism. Endocr Rev 1993, 14(2):165-183.

75. Ris-Stalpers C, Bikker $\mathrm{H}$ : Genetics and phenomics of hypothyroidism and goiter due to TPO mutations. Mol Cell Endocrinol 2010, 322(1-2):38-43.

76. Zamproni I, Grasberger H, Cortinovis F, Vigone MC, Chiumello G, Mora S, Onigata K, Fugazzola L, Refetoff S, Persani L, Weber G: Biallelic inactivation of the dual oxidase maturation factor 2 (DUOXA2) gene as a novel cause of congenital hypothyroidism. J Clin Endocrinol Metab 2008, 93(2):605-610.

77. Hoste C, Rigutto S, Van Vliet G, Miot F, De Deken X: Compound heterozygosity for a novel hemizygous missense mutation and a partial deletion affecting the catalytic core of the H2O2-generating enzyme DUOX2 associated with transient congenital hypothyroidism. Hum Mutat 2010, 31(4):E1304-E1319.

78. Moreno JC, Bikker H, Kempers MJ, van Trotsenburg AS, Baas F, de Vijlder JJ, Vulsma T, Ris-Stalpers C: Inactivating mutations in the gene for thyroid oxidase 2 (THOX2) and congenital hypothyroidism. N Engl J Med 2002, 347(2):95-102.

79. Moreno JC, Visser TJ: Genetics and phenomics of hypothyroidism and goiter due to iodotyrosine deiodinase (DEHAL1) gene mutations. Mol Cell Endocrinol 2010, 322(1-2):91-98.

80. Moreno JC, Klootwijk W, van Toor H, Pinto G, D'Alessandro M, Leger A, Goudie D, Polak M, Gruters A, Visser TJ: Mutations in the iodotyrosine deiodinase gene and hypothyroidism. N Engl J Med 2008, 358(17):1811-1818.

81. Levy-Shraga Y, Tamir L, Boyko V, Lerner-Geva L, Pinhas-Hamiel O: Follow up of newborns of mothers with Graves' disease. Thyroid 2014, Epub ahead of print. doi:10.1089/thy.2013.0489.

82. Isotani H, Sanda K, Kameoka K, Takamatsu J: McCune-Albright syndrome associated with non-autoimmune type of hyperthyroidism with development of thyrotoxic crisis. Horm Res 2000, 53(5):256-259.

83. Congedo V, Celi FS: Thyroid disease in patients with McCune-Albright syndrome. Pediatr Endocrinol Rev 2007, 4(Suppl 4):429-433.

84. Hershman JM: Physiological and pathological aspects of the effect of human chorionic gonadotropin on the thyroid. Best Pract Res Clin Endocrinol Metab 2004, 18(2):249-265.

85. Ishihara T, Waseda N, Ikekubo K, Kuroda K, Akamizu T, Mori T: A predicted case with neonatal transient hypothyroidism due to blocking type thyrotropin binding inhibitor immunoglobulins (TBII). Endocrinol Jpn 1985, 32(1):189-194.

86. Sato K, Okamura K, Yoshinari M, Ikenoue H, Kuroda T, Torisu M, Fujishima M: Goitrous hypothyroidism with blocking or stimulating thyrotropin binding inhibitor immunoglobulins. J Clin Endocrinol Metab 1990 71(4):855-860.

87. Persani L, Calebiro D, Cordella D, Weber G, Gelmini G, Libri D, de Filippis T, Bonomi M: Genetics and phenomics of hypothyroidism due to TSH resistance. Mol Cell Endocrinol 2010, 322(1-2):72-82.

88. Persani L, Gelmini G, Marelli F, Beck-Peccoz P, Bonomi M: Syndromes of resistance to TSH. Ann Endocrinol 2011, 72(2):60-63.

89. Balavoine AS, Ladsous M, Velayoudom FL, Vlaeminck V, Cardot Bauters C, d'Herbomez M, Wemeau JL: Hypothyroidism in patients with pseudohypoparathyroidism type la: clinical evidence of resistance to TSH and TRH. Eur J Endocrinol 2008, 159(4):431-437.

90. Pinsker JE, Rogers W, McLean S, Schaefer FV, Fenton C: Pseudohypoparathyroidism type 1a with congenital hypothyroidism. J Pediatr Endocrinol Metab 2006, 19(8):1049-1052.

91. Joshi R, Kapdi M: Pseudohypoparathyroidism type 1b with hypothyroidism. Indian Pediatr 2012, 49(8):667-668.

92. Leung AM, Braverman LE: Consequences of excess iodine. Nat Rev Endocrinol 2014, 10(3):136-142.

93. Danzi S, Klein I: Amiodarone-Induced Thyroid Dysfunction. J Intensive Care Med 2013, 2013:2013.

94. Cohen-Lehman J, Dahl P, Danzi S, Klein I: Effects of amiodarone therapy on thyroid function. Nat Rev Endocrinol 2010, 6(1):34-41.

95. Bogazzi F, Tomisti L, Bartalena L, Aghini-Lombardi F, Martino E: Amiodarone and the thyroid: a 2012 update. J Endocrinol Investig 2012, 35(3):340-348.

96. Bogazzi F, Bartalena L, Martino E: Approach to the patient with amiodarone-induced thyrotoxicosis. J Clin Endocrinol Metab 2010, 95(6):2529-2535

97. Bogazzi F, Bartalena L, Gasperi M, Braverman LE, Martino E: The various effects of amiodarone on thyroid function. Thyroid 2001, 11(5):511-519.

98. Mushtaq U, Price T, Laddipeerla N, Townsend A, Broadbridge V: Contrast induced hyperthyroidism due to iodine excess. BMJ Case Reports 2009, doi:10.1136/bcr.06.2009.1982.

99. Burgi H: lodine excess. Best Pract Res Clin Endocrinol Metab 2010, 24(1):107-115.

100. Roti E, Uberti ED: lodine excess and hyperthyroidism. Thyroid 2001 11(5):493-500.

101. Leung AM, Braverman LE: lodine-induced thyroid dysfunction. Curr Opin Endocrinol Diabetes Obes 2012, 19(5):414-419.

102. Barbesino G: Drugs affecting thyroid function. Thyroid 2010, 20(7):763-770.

103. Lazarus JH: Lithium and thyroid. Best Pract Res Clin Endocrinol Metab 2009, 23(6):723-733.

104. Kibirige D, Luzinda K, Ssekitoleko R: Spectrum of lithium induced thyroid abnormalities: a current perspective. Thyroid Res 2013, 6(1):3.

105. Roberto L: Lithium clearly and directly affects the activity of the thyroid gland in human. Hum Psychopharmacol 2010, 25(7-8):586. author reply 587.

106. Huang SA, Tu HM, Harney JW, Venihaki M, Butte AJ, Kozakewich HP Fishman SJ, Larsen PR: Severe hypothyroidism caused by type 3 iodothyronine deiodinase in infantile hemangiomas. N Engl J Med 2000, 343(3):185-189.

107. Huang SA, Fish SA, Dorfman DM, Salvatore D, Kozakewich HP, Mandel SJ, Larsen PR: A 21-year-old woman with consumptive hypothyroidism due 
to a vascular tumor expressing type 3 iodothyronine deiodinase. J Clin Endocrinol Metab 2002, 87(10):4457-4461.

108. Maynard MA, Marino-Enriquez A, Fletcher JA, Dorfman DM, Raut CP, Yassa L, Guo C, Wang Y, Dorfman C, Feldman HA, Frates MC, Song H, Jugo RH, Taguchi T, Hershman JM, Larsen PR, Huang SA: Thyroid hormone inactivation in gastrointestinal stromal tumors. N Engl J Med 2014 370(14):1327-1334.

109. Eskandari S, Loo DD, Dai G, Levy O, Wright EM, Carrasco N: Thyroid Na+/lsymporter. Mechanism, stoichiometry, and specificity. J Biol Chem 1997, 272(43):27230-27238.

110. Leung AM, Braverman LE, He X, Schuller KE, Roussilhes A, Jahreis KA, Pearce EN: Environmental perchlorate and thiocyanate exposures and infant serum thyroid function. Thyroid 2012, 22(9):938-943.

111. Leung AM, Pearce EN, Braverman LE: Perchlorate, iodine and the thyroid. Best Pract Res Clin Endocrinol Metab 2010, 24(1):133-141.

112. Environmental Protection Agency. [http://water.epa.gov/drink/ contaminants/unregulated/perchlorate.cfm]

113. Dohan O, Portulano C, Basquin C, Reyna-Neyra A, Amzel LM, Carrasco N: The $\mathrm{Na}+/ /$ symporter (NIS) mediates electroneutral active transport of the environmental pollutant perchlorate. Proc Natl Acad Sci U S A 2007, 104(51):20250-20255.

114. Kirk AB, Martinelango PK, Tian K, Dutta A, Smith EE, Dasgupta PK: Perchlorate and iodide in dairy and breast milk. Environ Sci Technol 2005 39(7):2011-2017.

115. Pearce EN, Leung AM, Blount BC, Bazrafshan HR, He X, Pino S, ValentinBlasini L, Braverman LE: Breast milk iodine and perchlorate concentrations in lactating Boston-area women. J Clin Endocrinol Metab 2007, 92(5):1673-1677.

116. Leung AM, Pearce EN, Hamilton T, He X, Pino S, Merewood A, Braverman LE: Colostrum iodine and perchlorate concentrations in Boston-area women: a cross-sectional study. Clin Endocrinol 2009, 70(2):326-330.

117. Braverman LE, Pearce EN, He X, Pino S, Seeley M, Beck B, Magnani B, Blount $B C$, Firek $A$ : Effects of six months of daily low-dose perchlorate exposure on thyroid function in healthy volunteers. J Clin Endocrinol Metab 2006, 91(7):2721-2724

118. Laurberg $P$, Nohr SB, Pedersen KM, Fuglsang E: lodine nutrition in breastfed infants is impaired by maternal smoking. J Clin Endocrinol Metab 2004, 89(1):181-187.

119. Wiersinga WM: Smoking and thyroid. Clin Endocrinol 2013, 79(2):145-151.

120. Andersen SL, Olsen J, Wu CS, Laurberg P: Smoking reduces the risk of hypothyroidism and increases the risk of hyperthyroidism: evidence from 450842 mothers giving birth in Denmark. Clin Endocrinol 2014 80(2):307-314

121. Steinmaus $C$, Miller MD, Cushing L, Blount BC, Smith AH: Combined effects of perchlorate, thiocyanate, and iodine on thyroid function in the National Health and Nutrition Examination Survey 2007-08. Environ Res 2013, 123:17-24

122. Gatseva PD, Argirova MD: High-nitrate levels in drinking water may be a risk factor for thyroid dysfunction in children and pregnant women living in rural Bulgarian areas. Int J Hyg Environ Health 2008, 211(5-6):555-559.

123. Tajtakova M, Semanova Z, Tomkova Z, Szokeova E, Majoros J, Radikova Z, Sebokova E, Klimes I, Langer P: Increased thyroid volume and frequency of thyroid disorders signs in schoolchildren from nitrate polluted area. Chemosphere 2006, 62(4):559-564.

124. Cooper DS: Antithyroid drugs. N Engl J Med 2005, 352(9):905-917.

125. Doerge DR, Chang HC: Inactivation of thyroid peroxidase by soy isoflavones, in vitro and in vivo. J Chromatogr B Analyt Technol Biomed Life Sci 2002, 777(1-2):269-279.

126. Fitzpatrick M: Soy formulas and the effects of isoflavones on the thyroid. N Z Med J 2000, 113(1103):24-26.

127. Messina M, Redmond G: Effects of soy protein and soybean isoflavones on thyroid function in healthy adults and hypothyroid patients: a review of the relevant literature. Thyroid 2006, 16(3):249-258.

128. Merritt RJ, Jenks BH: Safety of soy-based infant formulas containing isoflavones: the clinical evidence. J Nutr 2004, 134(5):1220S-1224S.

129. American Thyroid Association Guidelines Taskforce on Thyroid N, Differentiated Thyroid C, Cooper DS, Doherty GM, Haugen BR, Kloos RT, Lee SL, Mandel SJ, Mazzaferri EL, Mclver B, Schlumberger M, Sherman SI, Steward DL, Tuttle RM: Revised American Thyroid Association management guidelines for patients with thyroid nodules and differentiated thyroid cancer. Thyroid 2009, 19(11):1167-1214.

130. Lee $J$, Anzai Y: Imaging of thyroid and parathyroid glands. Semin Roentgenol 2013, 48(1):87-104.

131. Joyce JM, Swihart A: Thyroid: nuclear medicine update. Radiol Clin North Am 2011, 49(3):425-434.

132. Wahl RL: Thyroid Radionuclide uptake and imaging studies. In Werner \& Ingbar's The Thyroid. 10th edition. Edited by Braverman LE. Philadelphia: Lippincott Williams and Wilkins; 2013.

133. Takeuchi K, Suzuki H, Horiuchi Y, Mashimo K: Significance of iodideperchlorate discharge test for detection of iodine organification defect of the thyroid. J Clin Endocrinol Metab 1970, 31(2):144-146.

134. Khan SU, Khan AU, Khan A, Khan K, Ullah H: Thyroid dyshormonogenesis detected through a modified perchlorate discharge test using a gammacamera. Nucl Med Commun 2009, 30(7):574-576.

135. Leslie WD: Thyroid scintigraphy and perchlorate discharge test in the diagnosis of congenital hypothyroidism. Eur J Nucl Med 1996, 23(2):230.

136. Reiners C, Schneider R: Potassium iodide (KI) to block the thyroid from exposure to I-131: current questions and answers to be discussed. Radiat Environ Biophys 2013, 52(2):189-193.

137. Ho AL, Grewal RK, Leboeuf R, Sherman EJ, Pfister DG, Deandreis D, Pentlow KS, Zanzonico PB, Haque S, Gavane S, Ghossein RA, Ricarte-Filho JC, Domínguez JM, Shen R, Tuttle RM, Larson SM, Fagin JA: Selumetinibenhanced radioiodine uptake in advanced thyroid cancer. $N$ Engl J Med 2013, 368(7):623-632

138. Wapnir IL, van de Rijn M, Nowels K, Amenta PS, Walton K, Montgomery K, Greco RS, Dohan O, Carrasco N: Immunohistochemical profile of the sodium/iodide symporter in thyroid, breast, and other carcinomas using high density tissue microarrays and conventional sections. J Clin Endocrinol Metab 2003, 88(4):1880-1888.

139. Fischer AJ, Lennemann NJ, Krishnamurthy S, Pocza P, Durairaj L, Launspach $J \mathrm{~L}$, Rhein BA, Wohlford-Lenane C, Lorentzen D, Banfi B, McCray PB J: Enhancement of respiratory mucosal antiviral defenses by the oxidation of iodide. Am J Respir Cell Mol Biol 2011, 45(4):874-881.

140. Spitzweg C, Dietz AB, O'Connor MK, Bergert ER, Tindall DJ, Young CY, Morris JC: In vivo sodium iodide symporter gene therapy of prostate cancer. Gene Ther 2001, 8(20):1524-1531.

doi:10.1186/1687-9856-2014-8

Cite this article as: Pesce and Kopp: lodide transport: implications for health and disease. International Journal of Pediatric Endocrinology 2014 2014:8.

\section{Submit your next manuscript to BioMed Central and take full advantage of:}

- Convenient online submission

- Thorough peer review

- No space constraints or color figure charges

- Immediate publication on acceptance

- Inclusion in PubMed, CAS, Scopus and Google Scholar

- Research which is freely available for redistribution 